\title{
Theological Review for Tambak Development of Batak Toba Community
}

\author{
Theresia Tiodora Sitorus ${ }^{1}$, Jamin Tanhidy ${ }^{2}$, Stuart Guild ${ }^{3}$ \\ ${ }^{1}$ Universitas Kristen Satya Wacana, Salatiga, Indonesia \\ ${ }^{2}$ Sekolah Tinggi Teologi Simpson Ungaran, Indonesia \\ ${ }^{3}$ Trinity Evangelical Divinity School, United States \\ email: jamintan92@gmail.com
}

\begin{abstract}
Building and moving ponds or ancestral graves in the Toba Batak community, who have become Christians, is still practised today. The practice of building ponds is, of course, contrary to God's word, for that it needs to be responded to theologically and is the goal of this research. The method used is a descriptive qualitative method by reviewing the literature related to the research topic and reporting the findings in a description. The study results are as follows: First, building a pond with the motivation of asking for blessings from the ancestors is an act of sin. The gift of both physical and spiritual life comes from God and not the spirits of the ancestors. Second, moving and caring for ponds is wrong to prevent sickness and family quarrels because Christ bore all curses and diseases on the cross. Third, building a pond as a tribute to parents is wrong. The fifth commandment in Exodus 20:12 concerns respect for parents. It cannot be opposed to supporting the practice of building ponds. The substance of this verse is not only related to relations between humans but concerns God's blessing for His people to glorify God, the Creator, not ancestral spirits.
\end{abstract}

Keywords: Tambak, Theological Review, Batak Toba Community

\begin{abstract}
Abstrak: Praktek membangun dan memindahkan tambak atau kuburan leluhur dalam masyarakat Batak Toba, yang sudah menjadi orang Kristen, masih dilakukan sampai sekarang. Praktek pembangunan tambak tersebut tentu saja bertentangan dengan firman Tuhan, untuk itu perlu ditanggapi secara teologis dan menjadi tujuan penelitian ini. Metode yang dipakai ialah metode kualitatif deskriptif dengan mengkaji literatur berkaitan dengan topik penelitian dan melaporakan temuan dalam bentuk deskripsi. Hasil penelitian sebagai berikut: Pertama, membangun tambak dengan motivasi meminta berkat kepada leluhur adalah tindakan dosa. Berkat kehidupan baik jasmani dan rohani berasal dari Allah dan bukan roh-roh leluhur. Kedua, memindahkan dan mengindahkan tambak dengan tujuan untuk menolak sakit penyakit dan pertengkaran keluarga adalah keliru, karena Kristus telah menanggung semua kutuk dan penyakit di kayu salib. Ketiga, membangun tambak sebagai penghormatan kepada orang tua adalah salah menurut ajaran Alkitab. Hukum kelima dalam Keluaran 20:12 tentang menghormati orang tua, tidak dapat menjadi ayat penyokong praktik pembangunan tambak. Ayat ini substansinya tidak hanya berkaitan dengan relasi antar manusia tetapi menyangkut berkat Allah bagi umat-Nya, untuk memuliakan Tuhan, Sang Pencipta bukan arwah leluhur.
\end{abstract}

Kata Kunci: Tambak, Tinjauan Teologi, Masyarakat Batak Toba

\section{Introduction}

The Batak Toba tribe is one of the five Batak tribes that live in North Sumatra, Indonesia, especially in Samosir Island and Toba Lake. The others tribes are the Karo, Simalungun, Pakpak and Mandailing (Sinaga, 2016). The Batak Toba group has many traditions which still existed until now, and they can be seen in many events like giving birth, putting a name for babies, marriage, and burial ceremony. One of the Batak Toba customs is known as tambak, a monument that functions as a tomb of the ancestors. This sacred monument can be seen in the causeway between Pematang Siantar and Balige city. 
The construction of tambak is costly and collected from each member of the family. The special event, called margugu, is held to raise funds for building tambak (Sibarani, 2018). The monument looks like a small house with tiered roofs, ceramics, bricks, and other materials, including light and decorative lamps. This small grave building is one of the most prominent Batak Tobak traditions. After finishing the construction, the descendants will organize the inauguration ceremony called mamestahon. The monument represents a group's social status, and communities compete with each other by making luxurious tambaks to show their class in the community (Firmando, 2020). With this grand monument, the community will know which clan or marga has a considerable family, prosperity, and prestige. Because construction for tambaks is costly (Dessy Putri, Jurusan Ilmu Komunikasi, \& Hubungan Masyarakat, 2015), families often face dilemmas with their budgeting - whether to spend money on the ancestors or the family's needs such as tuition, house renovation fees, and so on. According to the tradition of building a tambak, each family member is responsible for funding the monument's construction. The dollar amount is one that all family members have to approve based on their status in the clan or according to the favor of each other. The provision for building tambak demands awareness for each member in the family, especially since each of the Batak Toba groups has their status referred to as Dalihan Natolu specifically hula-hula (family of the wife-giving party), and boru (the receiving party of the wife) be socially responsible than others to pay the cost of the construction. Batak people who have become Christians usually build and beautify ponds due to the belief that their ancestors can provide protection and prosperity blessings. This belief is an animist teaching as well as a syncretistic practice because it expects blessings from the spirits of the dead, this of course needs to be criticized biblically. Therefore, this paper is a theological response to the practice of building ponds in the Toba Batak community.

\section{Method}

This article uses the qualitative-descriptive research method, which describes a social or religious condition applied in the spiritual domain (Zaluchu, 2020, 2021). This research was taken based on the Toba Batak community, especially the HKBP Marihat II church group in the Siantar Marihat District, Pematangsiantar (Sugiyono, 2013). Related to the natural and economic resources in this sub-district, the most common occupations of church members include farmers, small goods sellers, drivers, and workers. The church members of HKBP Marihat II have already constructed many tambak. Therefore, it is a suitable setting for research into this important phenomenon.

\section{Result and Discussion}

\section{History and Meaning}

The monument call tambak in the Batak Toba community was known for a long time before Christianity existed in Batak lands. It is proven by many constructions made by stone, such as grave name paromasan, sarcophagi, jars, cubes, and carvings. All this stuff indicated that the burial tradition had been established during the megalithic period about $3000 \mathrm{BC}$. This tradition describes that the Batak Toba community believes and connects with their ancestral spirits and still influences the descendants, particularly in the Samosir Island (Wiradnyana \& Setiawan, 2013).

Tambak is a place made of stone to store the bones or saring-saring from one grandfather lineage collected from generation to generation (Aritonang, 2006). This monument has religious and cultural 
meanings for Batak Toba people all over the world. The construction strengthened the community and integrated them under the line of one ancestor (Siahaan, 1979, p. 14). When taking the bones from the burial, they use the service of someone called Dukun or mediator to connect to the deads' spritit and avoid the wrath of the spirits. This ritual named as mangongkal holi, and already became a tradition where the Batak Toba community remove their ancestors and parent's bones to a new place as an honor to their forefathers and gain benefits such as prosperity, wealth, and prestige from this ritual (Parningotan, 2017).

The splendor of the tambak is a sign of wealth or prosperity the descendants have received from their ancestors and symbolized the ancestors' greatness. The spirits deserve a place of honor and respect from the descendants or pinomparna (Corry, Napitu, Supsiloani, \& Ulung Napitu, 2020; Corry, Napitu, Supsiloani, \& Napitu, 2020; Ulung Napitu, Corry, Resna Napitu, \& Supsiloani, 2020).

The construction of the tambak carried out some meanings to the Batak Toba people. The purpose consists of eight parts; first, the sacred essence. The heeding of tambak indicates that the ancestors in the Batak Toba group or family are respected by their descendants during their life and still worshiped or honored after they died. The second, the existence of the ancestors. The Batak Toba group believes that heeding the construction of tambak makes the ancestors gained a high prestige or honor in nature. Third, the meaning of blessing. Through the ritual mangongkal holi the descendants will be blessed by their ancestors. Fourth, the purpose of brotherhood. The monument called tambak reaffirms spiritual ties and brotherhood between the descendants, including solidarity. Fifth, the cultural meaning. The object called tambak as a cultural meaning can be seen by its symbol and meanings. Sixth, the purpose of conflict resolution. The development of this object can be functioning to resolved the member of family or siblings conflict. Seventh, the meaning of social status. The building and heeding of tambak for the Batak Toba community can raise the descendant's social status. The descendants who owned a luxurious monument have a great man in the family line, such as the state official or business people. This meaning became a system belief among the Batak Toba community because the descendants who have a great social status, wealth, and prosperity believe that all these blessings came from their ancestors. This is why the community is willing to spend a lot of money by digging up the bones of their ancestors and putting them in better and luxurious buildings. Eight, the meaning of social prestige. The structure and heeding the monument named tambak also as a desire to increase social status in the society, personally and the family. That is why the ritual is celebrating by holding festive parties when the ritual mangongkal holi took place. The community has a philosophy of life or worldview named "Three H's" or three $\mathrm{H}$ letters. 1) Hamoraon. It means wealth. The group upholds hamoraon as a virtue or fundamental belief, while poverty is recognized as bad luck. In ancient times, the property consisted of farms, livestock, houses, and gold. 2) Hagabeon. It means to have many children. The philosophy of Hagabeon for Batak Toba society means the family has baoa or male and boru or female descendants. It is wellknown as: maranak sappulu pitu marboru sappulu onom dan falsafah bittang na rumiris oppu pe so ro, anak pe riris nang boru pe torop. If a family in this group has many grandchildren from all his sons and daughters who have married and could see his great-grandchildren, the family is called gabe. It is symbolized that the meaning of Hagabeon has became accomplished and characterized a perfect life of the Batak Toba people. 3) Hasangapon. This word is defined as an honorable, praiseworthy model of life and almost perfect. If someone in the family is considered sangap, he becomes a person who has achieved a high status in life and rarely complains from others. Usually, a 
person who labeled sangap has a hamoraon (wealthy or prosperity) and hagabeon (have a large and blessed family) either (Corry, Napitu, Supsiloani, \& Napitu, 2020).

Many factors encouraged the Batak Toba people to develop tambak. First, the increase of economic capacity in the members of the family or the descendants. Many of them live in many places or big cities out of North Sumatra. Their sons and daughters who have gained a more prosperous life tend to be a reason to heeding the tambak monument as a symbol of high social status in the community. This successful and wealthy condition also brings the family's prestige to the village. The descendants considered that all the prosperity, prosperous and healthy they have is part of the gift, or pasu-pasu means blessing from their ancestors (sumangot).

Second, to unifying the family. The Batak Toba proverb says, "Hau na pajonokjonok do marsiososan" which often happens in close family conflicts (Sijabat, 2003). It can be concluded that establishing a tambak is to unify all the family members' hearts and minds under the authority of their ancestors. The conflicts that happened in the family members often correlated to the bones of their ancestors have not been moved to a better place. If they missed this thing, the conflict will remain, including sickness, and assumed as a disaster by this society. Therefore, the grave or heeding's development seems reasonable to hold on to, which can be seen in a ritual known as mangongkal holi as an obligation.

Third, to conduct brotherhood among the descendants. A party like mangongkal holi is sponsored or financed by one family, but every head of the family under the lineage should be involved. The donation size is not the issue, and the priority is to embrace the family members to gain brotherhood. When the party mangongkal holi is going on, they dance together to create intimacy and unity (Siahaan, 1979).

Forth, to respect their parents. The community of Batak Toba dig up the bones of their ancestors and build a monument called tambak as a tribute to their parents or ancestors.

Fifth, to expect blessings from the ancestors. Usually, before the construction of tambak begins, many family members praying to their ancestors ask for gifts for a better life of family, health, and prosperity and using some particular foods as offerings named sesajen.

\section{Procedure and Impact}

The monument called tambak in Batak Toba society is a tomb that contains the bones of more than three generations of descendants, depending on the monument's size. During the party (Mangongkal holi), all the members dance and bind together as a massive family from the ancestors. The bones taken from the graves are usually put into a unique plate and then remove into a new coffin; after that, the party continues with a ritual of inserting it into a new tambak construction. The distance between the old burial and the new one named pinanangkok saringsaringna occurs after the meat has been seperated from the bones, estimated to be 6-7 years after dead (Silalahi, 2016).

In the Batak Toba society, two monuments are recognized but have the same meanings as a sign to respect ancestors' spirits. One is called tugu, and another one is tambak. The difference between the two monuments, namely First, is the shape of the monument. Tugu is formed like a statue, stone, or cone tower. Meanwhile, a monument named tambak is a grave whose the land is slighty elevated and has small rooms for bones covered with the traditional house of Batak Toba tradition at the top. The second, the building content. Tugu is only known as a memorial object for a clan named marga associated with. The monument aims to unify all the members as the same marga and help recognize their ancestors' 
history. Differently, the monument known as tambak is referred to a tomb being made in a high place where the bones of the deads from generations placed together in the same area (Sinambela, 2016).

In addition, the development of tambak in the Batak Toba community is a custom passed down from many generations, as the Batak's saying: "Tuat ma na dolok martungkot sialagundi, adat ni ompunta sijolo-jolo tubu siihuttonon ni na di pudi." Besides that, the monument called tambak in Batak Toba villages is quite a different one to another. There is a Batak Toba's saying: "Muba dolok muba duhutna, muba luat sai adong do muba adatna." During the construction of the tambak, the family holding a traditional party for three days or more, according to the family consolidation. This tradition named as Mangongkal holi. In this ceremony, those who have great wealth and prosperity usually cuuting buffalo called pinahan lobu, and required hula-hula. It means the clan from the wife's side must be invited to join the ceremony. The slaughter of buffalo indicates the prestige of the family. The prominent horn cut off, the more respected the family who held the tradition. Some of the tambak was built near to the church and city. The permit comes from the government and the family, as the monument owner of the monument will be charged some money to gain it. In addition, the position of tambak has to face the sun as a value system expressed in sayings: "Dompak mata ni ari."

The most interesting from this tradition is, the courage-building tambak is due to the request from the ancestors who have died. Many stories being told as an impact of buildings or heeding tambak. The positive impact is that the family does not divide as they being tied together as the same descendants. But the negative impact is the cost issue or family conflict related to how the model of tambak has to be established (Siregar, 2016).

\section{Theological Response}

The theological response means how we see the tradition of Batak Toba community system belief related to the way they are building or heeding tambak according to the Biblical account.

First, the Batak Toba people build and heeding tambak to gain blessings from their ancestor's spirit, known as pasu-pasu. Most Batak Toba people believe they can receive gifts from their ancestors when they build a tambak. The more luxurious the monument, the more incredible blessings, and higher social status will be gain for the family. The Bible itself used the terms tambak and tugu as the same meaning, a pillar or monument, particularly the reminder monument. In the Old Testament, the word tugu is used six times, generally designed for reminder constructions. For example, Jacob built a memorial at Bethel as a reminder that God has revealed to him in that place and considered a sacred place (Genesis 28:18) and reaffirmed his faith in the Lord in the same place when he has already gained blessings from The God of Abraham and Ishak, his ancestors. He gave an offering and poured oil on the monument (Genesis 35:14). In addition, several verses such as Exodus 23:24; 34:13; Deuteronomy 7:5; $12: 3$ emphasize that the pillar of idols must be destroyed because they are prohibited and hated by God (Leviticus 25:1; Deuteronomy 16:22). It can be a highlight that establishes an idol pillar or monument to worship another god besides Yahweh violates the covenant.

In the New Testament itself, the term monument is used only once where Jesus says to Jewish leaders, "woe to you, scribes and Pharisees, hypocrites because you build tombs of the prophets and adorn the pillars of the righteous (Sagala, 2011). The biblical account concludes that the motivation to build a monument is to worship God and remind His Majesty, who always protects, guides, accompanies, and blesses His people. 
If the biblical account above is implemented into the construction of the Batak Toba community, usually buidings and heeding ponds or pillars called tambak are contradicted. The monument of the Batak Toba community worships their ancestor's spirits and does not honor God's majesty and greatness. This is an act of idolatry represented by the descendants of Batak Toba people because they believe their ancestors spirits can give blessings to them. The Bible states explicitly that God forbids His people to seek guidance from the heart of the deads. This abomination idolatry practice was done by the Canaanites (Deuteronomy 18:11-12) that caused this nation punished by God and a threat of death penalty for the person who connected with the spirits of the dead (Leviticus 20:6).

Besides that, the Bible taught that the spirits of those who have died could no longer contact the living people, especially as the Christians who have already died were reunited with God and remain with Christ (Solihin, 2018). Believers who ask for guidance or blessings from the spirits of the dead are committed to sin and condemned by God because they have gain fortune and fellowship with an evil spirit (Liau, 2008). The Christianity view about the dead is that when a Christian has died, he lived the world forever and did not have any relationship with the living anymore. The blessings for human life are only obtained from the One Living God (Krisnando, Objantoro, \& Darmawan, 2019).

Second, The Batak Toba people held the ceremony called mangongkal holi, to rebuild and replace their ancestors' tomb with a new better place or new burial named tambak to avoid or reject cause or reinforcement. They still believe that all the conflicts or sickness they faced often caused by their ancestor's tomb have not been heeding and replace to a better place. This ceremony involves the services of a spiritual leader called Dukun or Shaman. This practice of worship to the dead spirits is contrary to the Christian faith. The Bible teaches that the followers of Christ had already received forgiveness of sins and being free from all the force of darkness (Colossians 1:13). The one who believed in Christ being guaranteed to receive healing from any diseases, because Christ Himself has borne the sins of the saints on the cross, and by His stripes every believer is healed (1 Peter 2:24). This means Jesus Christ has paid for all the curses and sickness at the cross (Galatians 3:13). As a result, God's blessings that promised to Abraham can be distributed to the Gentiles, the church, or everyone who have faith in Christ as a Savior (Galatians 3:14) and keep away from idolatry and magicians, etc. (Leviticus 20:6, 27; Deuteronomy 18:10, 11,14) which forbidden and condemned by God.

As Christians, the Batak Toba community should believe and rely on the Gospel's power to gain salvation and blessings and overcome misfortune, not by building and heeding tambak. Therefore, the HKBP church, specifically HKBP Marihat II, Siantar district, must consistently use all efforts to find a fresh way to approach or preach the Gospel of Jesus Christ to the Batak Toba people (Tanhidy, 2017, p. 50). In this case, the church's role needed to establish, especially reviewing the perspective of the Bible against the wrong system belief or value that caused the Batak Toba society to customize with tambak. The church should influence human society and bring the light of Christ in the mids of this sinful world.

Third, the tradition by building and heeding the constructions of tambak, as a respected remind for the parents or ancestors, including uniting the families existed positive value to the descendants. However, if it is associated with the worship of the spirits of the dead, the Bible speaks differently. Indeed, the scripture teaches God's people to honor their parents as recorded in Exodus 20:12: "Honor your father and your mother, so that you may live long in the land the LORD your God is giving you.." This verse describes the honor for the parents related to the blessings from the promised land that God's people will enter after being freed from slavery in Egypt, that is life long and the benefits from the ground, if the nation was maintaining His laws diligently (Matthew, 2019, p. 312). The implementation 
of this verse, the fifth law, concerning an obligation to honor parents but closely related to the blessings of the promised land that Jehovah has given to his people.

It can be concluded, and this fifth commandment implies that honoring parents who still alive is part of obeying God's law, and there are blessings for God's people who faithfully follow His commandments. Hence, the teaching of respect to the parents in this verse is not appropriate to support the practice of Batak Toba community practice on the way they respect their ancestors, which regarding as a practice of idolatry because it contains a mystical element is that asking the blessings from the spirits of the dead and therefore being curse by God.

However, in current system beliefs and practice of the monument called tambak, particularly Mangkongkal holi ceremony, has been regulated in the rules of the HKBP church, namely the HKBP Ruhut Parmahanion dohot Paminsangon (RPP), pages 47-48. These rules changed the performance of traditional leaders or Dukun and replaced them by the Pastor or God's servant who pray for the blessing of the Lord for the society. To hold this practice, the reason must be apparent by the rules of the HKBP organization, that is, to maintain solidarity, stability, and social cohesion of the Batak Toba community (Hutagaol \& P. Prayitno, 2020).

\section{Conclusion}

The philosophy behind the practice of beautifying ancestral graves known as "Tambak" in the Toba Batak community, North Sumatra relates to worshiping the spirits of the dead which is forbidden by the word of God. Asking for blessings from the ancestors is an act of sin, because the gift of both physical and spiritual life comes from God. It is wrong to beautify tambak to prevent sickness and family quarrels because Christ have already bore all curses and diseases on the cross. Therefore, building a pond as a tribute to parents is wrong according to biblical teachings. The interpretation about the fifth commandment in Exodus 20:12 concerning respect for parents cannot be opposed to supporting the practice of building ponds. The substance of this verse is not only related to relations between humans but concerns God's blessing for His people, to glorify God, the Creator, not ancestral spirits.

\section{References}

Aritonang, J. (2006). Beberapa Pemikiran Menuju Teologi Dalihan Na Tolu. Jakarta: Dian Utama. Corry, Napitu, U., Supsiloani, \& Napitu, R. (2020). Cultural Meaning of Monument Building in the Life of Toba Batak Tribe in Pangururan and Palipi Subdistricts, Samosir Regency. Britain International of Humanities and Social Sciences (BIoHS) Journal, 2(2), 392-402. https://doi.org/10.33258/biohs.v2i2.237

Firmando, H. B. (2020). Perubahan Sosial Dalam Upacara Adat Kematian Pada Etnis Batak Toba di Tapanuli Utara. Sosial Budaya, 17(2), 95-105. https://doi.org/10.24014/SB.V17I2.10300

Hutagaol, F. O., \& P. Prayitno, I. S. (2020). Perkembangan Ritual Adat Mangongkal Holi Batak Toba dalam Kekristenan di Tanah Batak. Anthropos: Jurnal Antropologi Sosial Dan Budaya (Journal of Social and Cultural Anthropology), 6(1), 84-92. https://doi.org/10.24114/antro.v6i1.16822

Krisnando, D., Objantoro, E., \& Darmawan, I. P. A. (2019). Konsep Teologi Injili Tentang Roh Orang Mati. Evangelikal: Jurnal Teologi Injili Dan Pembinaan Warga Jemaat, 3(1), 90-99. https://doi.org/10.46445/ejti.v3i1.136 
Liau, S. (2008). Pro dan Kontra mengenai Roh Samuel dalam 1 Samuel 28:1-25. Veritas : Jurnal

Teologi Dan Pelayanan, 9(2), 135-151. https://doi.org/10.36421/veritas.v9i2.199

Matthew, H. (2019). Kitab Keluaran, Imamat. Surabaya: Momentum.

Napitu, R., Corry, Supsiloani, \& Napitu, U. (2020). Samosir Regency in the Development of Monument. SIASAT, 5(2), 73-83. https://doi.org/10.33258/siasat.v5i2.58

Napitu, U., Corry, Napitu, R. \& Supsiloani. (2020). The Meaning of Monument in the Life of Toba Batak Tribe in Palipi Subdistrict, Samosir Regency, Indonesia. Konfrontasi: Jurnal Kultural, Ekonomi Dan Perubahan Sosial, 7(2), 124-136. https://doi.org/10.33258/konfrontasi2.v7i2.106

Parningotan, B. V. (2017). Ulaon Adat Mangongkal Holi pada Masyarakat Batak Toba di Kecamatan Sipahutar: Kajian Folklor. Universitas Sumatera Utara, Medan.

Putri, F. D., Nurjanah (2015). MAKNA SIMBOLIK UPACARA MANGONGKAL HOLI BAGI MASYARAKAT BATAK TOBA DI DESA SIMANINDO KECAMATAN SIMANINDO KABUPATEN SAMOSIR PROVINSI SUMATERA UTARA. Jom FISIP, 2(2), 1-15

Sagala, M. (2011). Injil dan Adat Batak. Jakarta: Yayasan Bina Dunia.

Siahaan, H. (1979). Persekutuan Agama Budaya Orang Batak Toba. Medan: HKBP.

Sibarani, R. (2018). Batak Toba society's local wisdom of mutual cooperation in Toba Lake area: A linguistic anthropology study. International Journal of Human Rights in Healthcare, 11(1), 40-55. https://doi.org/10.1108/IJHRH-08-2017-0035

Sijabat, M. S. (2003). Penggalian Tulang-Belulang: Sebuah Kritik Injili terhadap Pembangunan Tugu di Tapanuli Utara . Veritas: Jurnal Teologi Dan Pelayanan, 4(1), 67-86.

Silalahi, S. (2016). Interview.

Sinaga, L. (2016). Makna Tambak Bagi Etnis Batak Toba Di Kecamatan Lintong Nihuta Kabupaten Humbang Hasundutan. Universitas Negeri Medan, Medan.

Sinambela, A. (2016). Interview.

Siregar, T. (2016). Interview.

Solihin, B. (2018). Di Manakah Orang-Orang yang Telah Meninggal Dunia Berada? : Sebuah Studi Mengenai Intermediate State. Veritas : Jurnal Teologi Dan Pelayanan, 4(2), 225-237. https://doi.org/10.36421/veritas.v4i2.112

Sugiyono. (2013). Metode Penelitian Pendidikan Pendekatan Kuantitatif, Kualitatif dan R\&D.

Tanhidy, J. (2017). Praktik Metode Penginjilan Pada Mata Kuliah Metode Penginjilan STT Simpson Ungaran. Evangelikal: Jurnal Teologi Injili Dan Pembinaan Warga Jemaat, 1(1), 49. https://doi.org/10.46445/ejti.v1i1.55

Wiradnyana, K., \& Setiawan, T. (2013). Wisata Arkeologi: Jejak Peninggalan Tradisi Megalitik di Kabupaten Samosir. Samosir: Dinas Pariwisata, Seni, dan Budaya.

Zaluchu, S. E. (2020). Strategi Penelitian Kualitatif dan Kuantitatif Di Dalam Penelitian Agama. Evangelikal: Jurnal Teologi Injili Dan Pembinaan Warga Jemaat, 4(1), 28-38. https://doi.org/10.46445/ejti.v4i1.167

Zaluchu, S. E. (2021). Metode Penelitian di dalam Manuskrip Jurnal Ilmiah Keagamaan. Jurnal Teologi Berita Hidup, 3(2), 249-266. https://doi.org/10.38189/jtbh.v3i2.93 